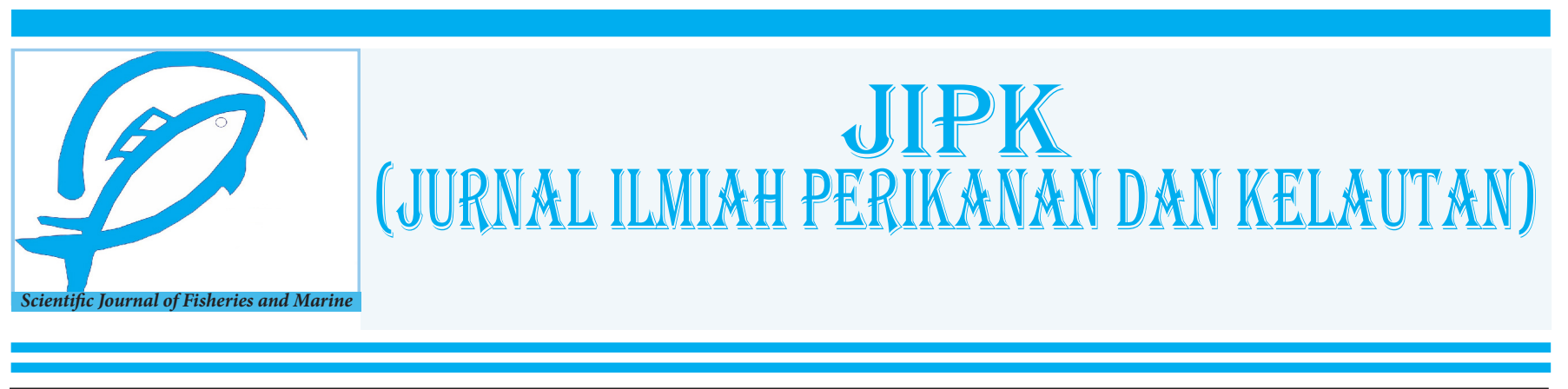

Research Article

\title{
Harvest Control Rules of Multispecies Scads (Decapterus spp.) Fishery in Blitar Waters, East Java
}

\section{Ledhyane Ika Harlyan ${ }^{1,2}$ (D), Shobriyyah Afifah Nabilah', Daduk Setyohadi', Muhammad Arif Rahman $^{1,2}$ and Supapong Pattarapongpan ${ }^{3}$}

${ }^{1}$ Faculty of Fisheries and Marine Science, University of Brawijaya, Malang, 65145. Indonesia

${ }^{2}$ Marine Resources Exploration and Management Research Group, University of Brawijaya, Malang, 65145. Indonesia

${ }^{3}$ Southeast Asian Fisheries Development Center, Training Department, Samutprakan. Thailand

\section{OPEN $\bigcirc$ ACCESS}

\section{ARTICLE INFO}

Received: October 14, 2021

Accepted: December 30, 2021

Published: December 31, 2021

*) Corresponding author:

E-mail: ledhyane@ub.ac.id

\section{Keywords:}

Allowable Biological Catch

Surplus Production Model

Feedback Harvest Control Rule Schaefer Model

Fox Model

This is an open access article under the CC BY-NC-SA license (https://creativecommons.org/ licenses/by-nc-sa/4.0/)
Abstract

Scads fishery in Blitar waters is a multispecies fishery applying harvest control rules (HCRs) from conventional single-species approaches which technically, may not be applicable to employ in such mixedspecies data composed from the multispecies fishery. The feedback HCR is an alternative validated harvest control rule that can be applied for a multispecies fishery. The aim of this study was to technically compare the application of the feedback HCR and conventional single species approaches in terms of estimating the future allowable biological catch (ABC). Therefore, in this study, ABC was estimated by applying three HCRs, the feedback HCR, and two conventional HCRs which was based on single-species approaches applying surplus production models, Schaefer Model and Fox model into catch and effort of scads fisheries data series of $2011-2020$. The results showed that the ABC estimation of the feedback HCR was a half lower than that of both conventional models. It was biologically safer to apply the feedback HCR to set the annual total allowable catch (TAC) than the other two HCRs. The feedback HCR presented an initial step toward sustainably managing multispecies fisheries while dealing with data-limited conditions.

Cite this as: Harlyan, L. I., Nabilah, S. A., Setyohadi, D., Rahman, M. A, \& Pattarapongpan, S. (2022). Harvest Control Rules of Multispecies Scads (Decapterus spp.) Fishery in Blitar Waters, East Java. Jurnal Ilmiah Perikanan dan Kelautan, 14(1):38-47. http://doi.org/10.20473/jipk.v14i1.30688 


\section{Introduction}

Scads (Decapterus spp.) is one of the pelagic resources that are intensively exploited and contributed to fisheries productivity. It is widely distributed in the Arafura Sea, Sunda shelf covering the Java Sea, and the South China Sea, the Southern Indian Ocean covering Java Sea, Banda Sea, also inhabiting Southern Java. In the southern Java, the scads fishery has been experiencing high variability in catch production. Particularly in Blitar regency, in recent years, the scads catches have been fluctuating which lead to a decreasing trend (Department of Fisheries and Marine Affairs East Java Province, 2020; Suwarso and Zamroni, 2014).

In Blitar Regency, scads fishery comprises of four species, redtail scads (D. kuroides), Indian scads (D. ruselli) and shortfin scads (D. macrosoma), Mackerel scads (D. macarellus). As fishing pressures increase, fishing capacity management has been applied to control and monitor the scads exploitation rate (Suwarso et al., 2014). A harvest control rule (HCR) system has been conducted to determine annual allowable biological catch $(\mathrm{ABC})$ which based on some conventional surplus production models with single-species approaches (Yanto et al., 2020).

Generally, some conventional surplus production models with single-species approach such as the Schaefer and Fox model, the Walter-Hilborn model, and the yield per recruit (YPR) model which have been frequently applied worldwide, including in multispecies fishery (Harlyan et al., 2019; Hilborn and Ovando, 2014; Newman et al., 2018). The approaches require species-specific biological information to be conducted (Cadrin and Dickey-Collas, 2015), which might be severely hard to attain in the majority multispecies fishery. Some argue that these single-species approaches might be not properly fit to be applied in multispecies fishery or in fishery which species-specific data could not be clarified (Harlyan et al., 2020, 2021; Hilborn and Ovando, 2014; Shertzer and Williams, 2008) .

In tropical fisheries, such as Indonesia, that commonly characterized as multispecies fishery, the assumptions of a single-species approach are relatively challenging to accomplish due to the use of multi-gear that catch various species (Harlyan et al., 2020; Punt et al., 2016). In fact, fisheries management remains based on what single-species model recommendation, where maximum sustainable yield (MSY) values are calculated for only a few key species without involving other minor species that are also parts of the multispecies fishery (Kvamsdal et al., 2016; Munehara et al., 2021).
In addition, some technical and financial limitations for performing species segregation are also caused by the unavailability of species-specific data (Yuniarta et al., 2017).

The feedback HCR (Tanaka, 1980; Chumchuen and Chumchuen, 2019; Ohshimo and Naya, 2014) is the successful HCR applied to Japanese fisheries management (Harlyan et al., 2019; Ichinokawa et al., 2017). It was introduced in 1997 as one of the fisheries management tools for data-poor fisheries, such as fisheries that biomass estimation is unavailable (Makino, 2011b). This feedback HCR was previously validated to be applied in multispecies fisheries with only mixed-species data available. Also, the sensitivity of the feedback HCR's performance over several scenarios of population dynamics was also examined and compared across other modified HCRs (Harlyan et al., 2019). This HCR can provide scientific recommendations to determine the annual $\mathrm{ABC}$ considering the previous stock abundance (Tanaka, 1980; Magnusson, 1992). In the feedback strategy, fish resources are assumed as a control system with catch quotas as output and stock abundance as inputs, so that the amount of catch quotas is determined to be close to the stock abundance (Goethel et al., 2019; Harlyan et al., 2019, 2020; Hoshino et al., 2012; Ohshimo and Naya, 2014) .

The application of the feedback HCR may provide the estimation of $\mathrm{ABC}$ with precautionary principle as single-species surplus production models. However, few reviews have demonstrated a scientific comparison of how the feedback HCR and the surplus production models produce the annual ABC. This study estimated the annual ABC for scads multispecies fishery in Blitar Regency by applying the validated feedback HCR. Therefore, the aim of this study is to generate a technical comparison between the feedback HCR and two surplus production models in terms of estimating the annual $\mathrm{ABC}$.

\section{Materials and Methods}

\subsection{Catch and Effort Data}

The source data was time-series catch-effort data gathered from the annual reports of the fisheries statistics data from 2011 to 2020 collected under the authority of the Department of Marine and Fisheries (DMF) East Java Province. The catch-effort data were collected from all sub-districts by enumerators based on the fishery logbook filled by fishers then were tabulated, validated, and verified in the districts and delivered to be published under the DMF East Java Province. The catch 
data was the scads landing data, while the effort data was the fishing trips of scads fishery in Tambakrejo fishing port, Blitar Regency (Figure 1). The fishing trips per year were calculated from all fishing gears employed to catch scads. There were six fishing gears operated in scad fisheries in Blitar Regency. They were purse seine, payang, drift gillnet, fixed gillnet, klitik net, and drift longline.

\subsection{Data Analysis}

Several data analyses were conducted to estimate the annual TAC by applying the feedback HCR, and a common HCR with conventional surplus production model approaches. The common HCR was performed by two models, Schaefer and Fox models. The catch per unit effort ratio was applied to express the stock abundance index for all scads species. Below are the details of formulas of each method, as follows:

\subsubsection{Catch per unit effort}

Catch per unit effort (CPUE) indicates the stock abundance index of scads that is calculated by this following formula:

$$
C P U E=\frac{C}{f}
$$

where $c$ and $f$ indicate catch (ton) and effort (fishing trips), respectively (Sparre and Venema, 1992).

\subsubsection{Effort standardization}

Effort standardization is data treatment to provide the standard of fishing effort of various fishing gears, which may differ from one to another. This method is practically used to find the standard fishing gear that produces the highest fishing effort over all gears. To compare the productivity of all gears, the fishing power index (FPI) is calculated for each gear. For the standard gear, the FPI is equal to 1 (Susanti et al., 2020).

$$
F P I=\frac{C P U E \text { of gear }}{C P U E \text { of standard gear }}
$$

The standardized effort for each fishing gear is calculated by the following formula:

$$
\text { The standardized effort }=F P I \times \text { effort }
$$

\subsubsection{Harvest control rules}

The annual ABC was estimated by applying three HCRs (i.e., two surplus production models, Schaefer and Fox models; and the feedback HCR) into catch and effort data of scads fishery in Blitar Regency as follows
(Harlyan et al., 2019; Ohshimo and Naya, 2014; Tanaka, 1980).

\subsubsection{Surplus production model}

In this study, two models were applied, Schaefer and Fox models. The calculation of surplus production models determines the MSY where the condition of stock can be exploited without any impacts for the following stock production. Under these models, it was assumed that the relationship between CPUE and effort has a negative correlation (Sparre and Venema, 1992).

\subsubsection{1 a Schaefer model}

The model is applied linear regression for CPUE and effort with the following formula:

$$
\begin{gathered}
\frac{c}{f}=a-b . f \\
f_{M S Y}=-\frac{a}{2 b} \\
C_{M S Y}=-\frac{a^{2}}{4 b}
\end{gathered}
$$

The $\mathrm{a}$ and $\mathrm{b}$ are the regression intercept and coefficient, respectively. The $f_{M S Y}$ indicates the effort that is consistent with achieving $M S Y$. In contrast, the $C_{M S Y}$ indicates the largest average catch or yield that can continuously be taken from a stock under existing environmental conditions.

\subsubsection{1b Fox model}

The Fox model also applied linear regression to estimate the MSY condition. However, instead of using CPUE, the linear regression was conducted by applying the natural logarithm of CPUE (ln CPUE) and effort with the following formula:

$$
\begin{aligned}
\operatorname{lnCPUE} & =a-b \cdot f \\
C_{M S Y} & =-\frac{1}{b} \cdot e^{a-1} \\
f_{M S Y} & =\frac{1}{b}
\end{aligned}
$$

Technically, the annual TAC is set at $80 \%$ of the estimated either using Schaefer or Fox model (Sartimbul et al., 2016).

\subsubsection{Feedback HCR}

The calculation of the feedback HCR resulted in the annual allowable biological catch for the year $y()$ The is recommended based on the overfishing limit to account for scientific uncertainty. Afterwards, the TAC can be set at a certain level which cannot exceed the recommended. The feedback HCR is applying the following formulas to calculate the (Harlyan et al., 2019): 


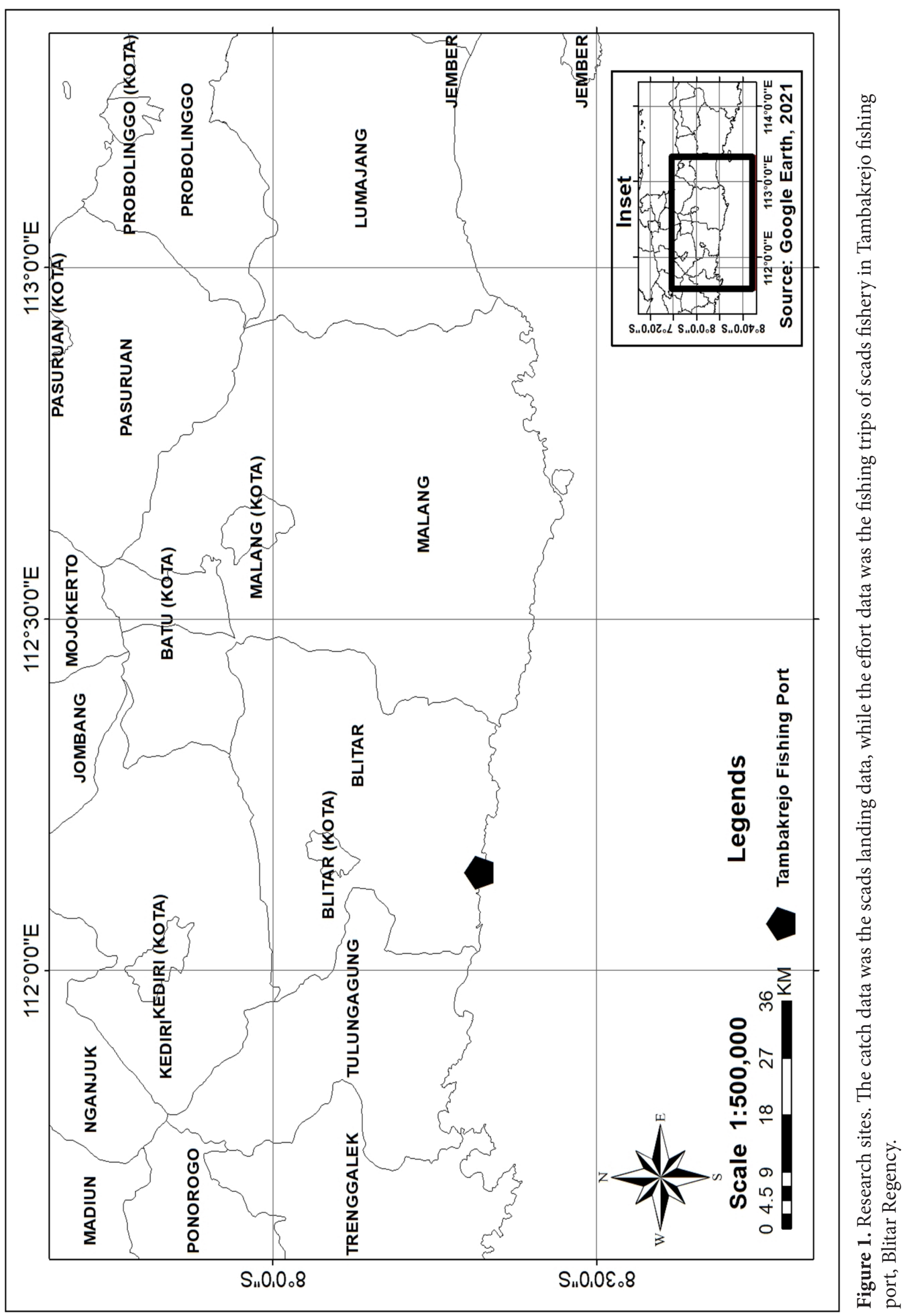


JIPK. Volume 14 No 1. April 2022 / Harvest Control Rules of Multispecies Scads (Decapterus spp.) Fishery in Blitar..

$$
\begin{aligned}
& A B C_{y}=\delta \times C_{y-2} \times \gamma \\
& \gamma=1+k \frac{b}{I}
\end{aligned}
$$

With is the weighting coefficient, which is set as 1,1 and 0.8 for stock level high, medium, and low, respectively. The stock levels are estimated from the trend of the stock abundance index of scads in $2011-2020$. In this study, CPUE was employed as the stock abundance index. The stock level determination was set by calculating the upper and the lower limit of the stock abundance index obtained from the $33^{\text {rd }}$ and $67^{\text {th }}$ percentiles of the $2011-2020$ data. The high stock level is defined if the recent CPUE value is higher than the upper limit, while the medium is in between the upper and lower limit. The low stock level is defined if the recent CPUE is lower than the lower limit. The indicated the catch of $\mathrm{y}-2$ (ton), the $k$ is the feedback factor (which is set $=1$ ), while indicated the trend of CPUE during the study period. The symbols $b$ and $I$ are defined as regression coefficient and the average of CPUE in the $y-4$ to $y-2$ (ton/day).

\subsubsection{Technical comparison among HCRs}

Technical comparison among HCRs was conducted to analyse the precautionary approach of each HCR to provide the annual TAC from. It was compared the amount of the TAC ( and the total allowable effort (TAE), i.e., the effort when achieving TAC (. The calculation of for two surplus production model were applied 0.8 of the , while the for the feedback HCR was the calculated $A B C_{\mathrm{y}}$.

\section{Results and Discussion}

\subsection{Results}

\subsubsection{Scads fishery in Blitar Regency}

The scads fishery increased in the number of landings from 2011 and peaked in 2018 (Figure 2). In the recent years, there were an increase of the number of purse seine as the standard gear for catching Scads that led to an increase in the number of trips. As a consequence, this would reduce the allocation of landings per trip (CPUE). Since several gears caught scads, the effort of fishing gear that caught scads must be standardized before, which was applied to the calculation of the annual TAC (Table 1).

Purse seine was determined as the standard gears for scad fishery. It indicated that this gear was a dominant gear over the other gears. The effort provided by purse seine was described in the ratio column. A purse seine trip was equal to 4 trips of payang, 61 trips of drift gillnet, 99 trips of fixed gillnet, 1779 trips of klitik gillnet and 800 trips of drift longline. As Tambakrejo fishers clarified, purse seine was frequently operated, since it produced the highest catch compared to other gears. Therefore, before further analyses, the effort of various gears was standardized into purse seine FPI (Table 1). To estimate the annual TAC using three model approaches; the Schaefer model, the Fox model, and the feedback HCR by applying into the catch-effort data in 2011 - 2020 (Table 2). The trend of CPUE has a negative slope indicating a decrease in CPUE due to increasing the number of trips.

Table 1. Effort standardization

\begin{tabular}{lrcc}
\hline \multicolumn{1}{c}{ Fishing gears } & $\begin{array}{c}\text { Fishing } \\
\text { productivity }\end{array}$ & FPI & Ratio \\
\hline Purse seine & 4717.02 & 1 & 1 \\
Payang & 1105.23 & 0.23 & 4 \\
Drift gillnet & 77.81 & 0.016 & 61 \\
Fixed gillnet & 47.6 & 0.01 & 99 \\
Klitik gillnet & 2.65 & 0.001 & 1779 \\
Drift longline & 5.89 & 0.001 & 800 \\
\hline
\end{tabular}

Description: Fishing productivity describes the amount of catch per trip (ton/trip), FPI (fishing power index) describes the comparison of productivity between gears.

\subsubsection{The Schaefer Model}

In the Schaefer model, the linear regression relationship between effort and CPUE showed a negative slope, which met the Schaefer model assumption (Figure 3). The linear regression model appears as, where the $95 \%$ confidence interval for the regression coefficient is ranged from to 0.0008 , and for constant is ranged from 2.0367 to 3.0767. It showed that an increase in fishing trips generated a decreased amount of the CPUE by 0.0013 tons. The determination coefficient stated that the value of CPUE was dependent on the fishing trips about $79.76 \%$, while the other $20.24 \%$ was affected by other factors.

The Schaefer curve was shaped parabolically to fit with the catch of scads during 2011 - 2020. Based on the model, the optimum catch was estimated about 1265.1 tons, while the optimum fishing effort was estimated about 990 trips. Therefore, the annual TAC was set at about 1012 tons and the allowable effort was 550 trips. 


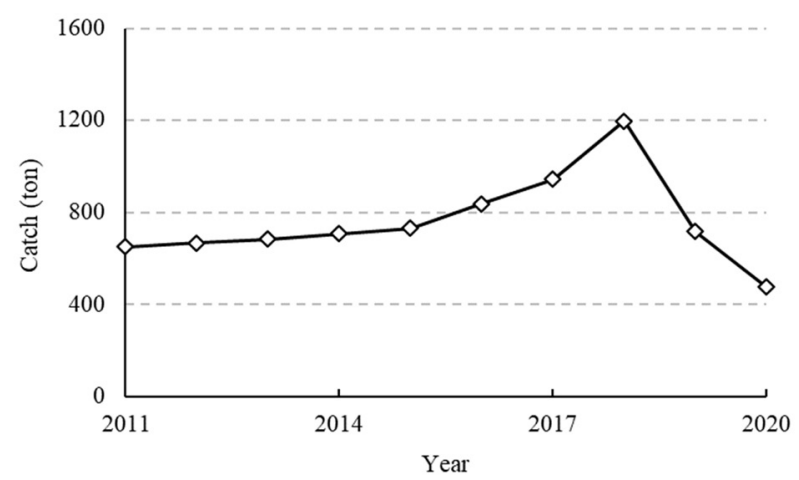

Figure 2. The catch of scads fishery in $2011-2020$

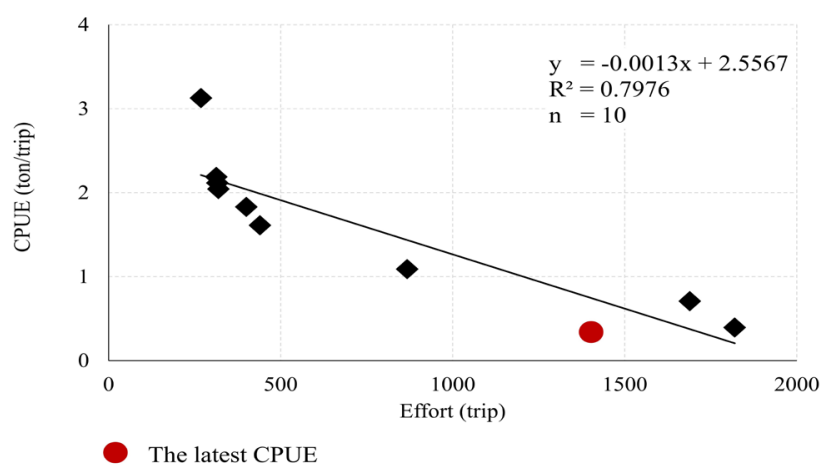

Figure 3. Linear regression of CPUE and effort

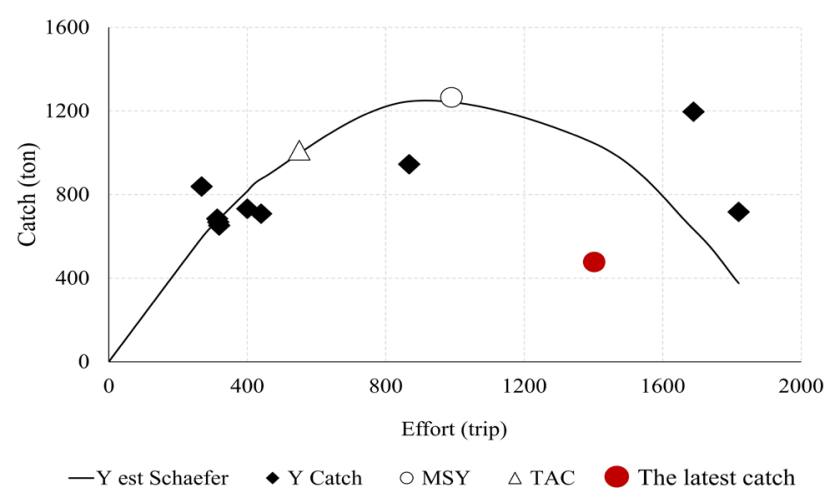

Figure 4. The relationship between catch and effort of scads fishery in Schaefer model

\subsubsection{The Fox model}

In the Fox model, the relationship between effort and $\ln$ CPUE was also portrayed in linear regression (Figure 5). The linear regression model appears as, where the $95 \%$ confidence interval for the regression coefficient is ranged from 0.00151 to 0.00078 , and the constant ranged from $0.76-1.48$. It was shown that an increase in fishing trips would lead to a decrease in the ln CPUE by 0.0011 tons. The relationship between these factors indicated the negative interaction, and it also met the assumptions of the Fox model (Figure 5). The determination coefficient gave $86.57 \%$, indicating that the increase of fishing trips affected the $\ln$ CPUE by $86.57 \%$.

In the Fox model, the catch - effort data was shaped exponentially that determining the optimum was about 981.7 tons, while the optimum effort was set about 874 trips. Considering these estimations, the annual TAC based on the Fox model was estimated as 785.38 tons and the allowable effort was 440 trips.

\subsubsection{The feedback HCR}

The determination of the annual TAC was expressed as allowable biological catch (in the feedback HCR. The stock levels ( $\delta$ ) were illustrated by defining the trend of CPUE in $2011-2020$ (Figure 7). The stock level ( $\delta$ ) performed in the low level so that it was set as 0.8 (Figure 7). The catch of two years before the estimated year ( was 716.8 tons (Table 2). The regression coefficient of $y-4$ to $y-2$ was -0.3475 , while the average CPUE from $\mathrm{y}-4$ to $\mathrm{y}-2$ was 0.73 tons/trip. The annual TAC was 300.6 ton and the annual TAEwas 763 trips.

\subsubsection{The comparison among HCRs}

The results of the annual TAC and TAE estimation were compared among HCRs (Table 3). In terms of the estimation of TAC, the Schaefer model provided the highest estimation at 1012 tons, while the feedback HCR generated the lowest estimation at 300.6 tons. In contrast, for the TAE estimation, the feedback HCR provided the higher estimation compared to the other two models.

\subsection{Discussion}

The feedback HCR is a practical application that can estimate the annual TAC or without assessing fish biomass as required by the common conventional surplus production models. In principle, this application considers stock abundance trends to determine the allowable biological catch for further use of catch quota policy (Harlyan et al., 2019; Ichinokawa et al., 2017).

Based on 10 to 20 years of historical data of fishing activities, the estimation of allowable biological catch and effort can be simply calculated. The historical data is the catch-effort data that has been validated. In some cases, the fishing effort could not be validated, instead of CPUE, catch data can be assumed as a stock abundance index (Harlyan et al., 2019; Ohshimo and Naya, 2014)which are categorized into two types depending on whether or not stock-size information is available. We evaluate management procedures (MPs. 
JIPK. Volume 14 No 1. April 2022 / Harvest Control Rules of Multispecies Scads (Decapterus spp.) Fishery in Blitar..

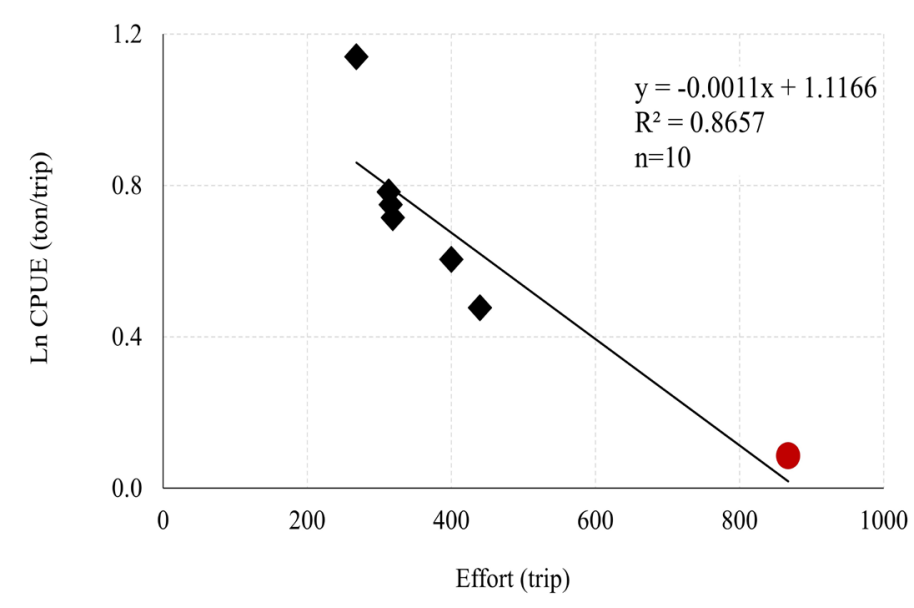

The latest CPUE

Figure 5. Linear regression of $\ln$ CPUE and effort

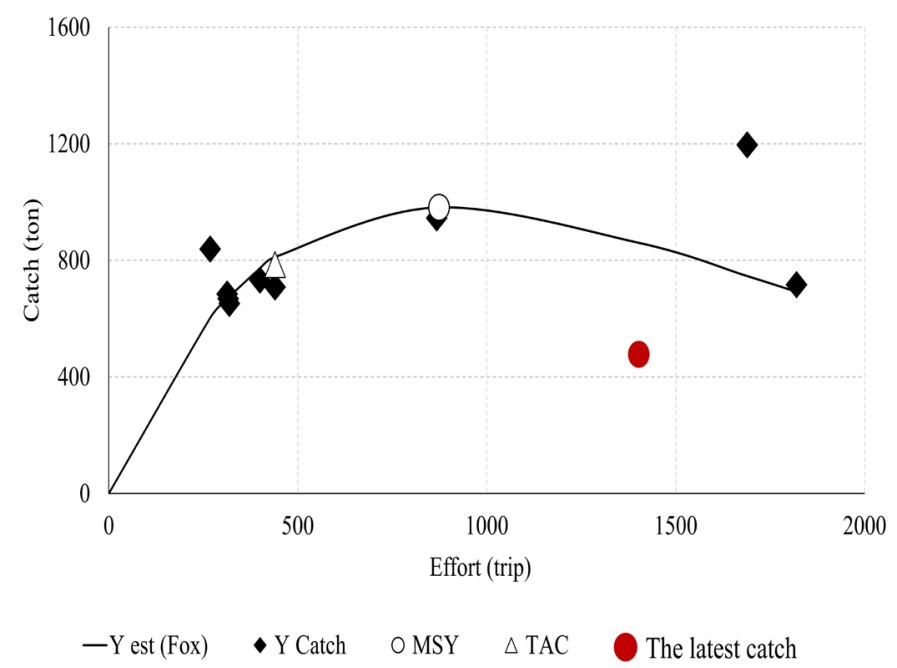

Figure 6. The relationship between catch and effort of scads fishery in Fox model

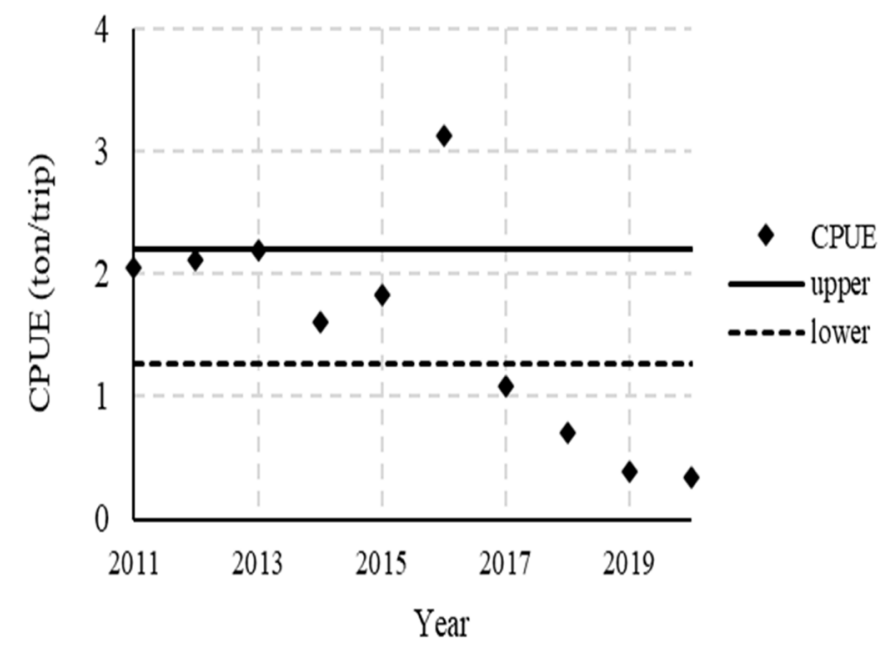

Figure 7. The stock abundance index (CPUE) of scads fishery in Blitar Regency in 2011 - 2020 with the upper and lower limits for determining stock status level in feedback HCR
Regarding data-poor fisheries management in some tropical countries that is struggling with fish stock assessment (Harlyan et al., 2021), the feedback HCR offers practical information with flexibility in data requirements compared to the conventional single-species surplus production models (Chumchuen et al., 2016; Harlyan et al., 2019; Kvamsdal et al., 2016; Makino, 2011a). Generally, Indonesian fisheries management apply a conventional single-species approach for some important species, including scads, tuna and mackerel (Chumchuen and Chumchuen, 2019; Harlyan et al., 2019, 2020).

In this study, three HCRs were performed, Schaefer and Fox models as conventional surplus production models and the feedback HCR to estimate the annual TAC along with the annual TAE. The results of all HCRs provided the annual TAC that is biologically safe since those applied precautionary approaches to avoid overfishing (Ichinokawa et al., 2015). Based on the calculation of the feedback HCR, the annual TAC was set a half lower than the ones that set by the Schaefer and Fox model. Technically, the different of basic calculation on the annual TAC of the three HCRs is in the two conventional surplus production models, the abundance index estimation (i.e., the b-value, regression coefficient) was considered for all years, however, in the feedback HCR, only the recent four years was considered to be calculated. In this study, the b-values were influenced by the high CPUEs during 2011-2016 and the low CPUEs during 2017-2020.

The historical catch shown in the stock levels has an important role to determine upcoming policy and fishing strategies (Harlyan et al., 2019; Magnusson, 1992). If a fishery has a low stock level (Kleisner et al., 2013), this fishery must be recovered by applying lower catch quotas (Carruthers et al., 2014; Dowling et al., 2015; Harlyan et al., 2019). While, on the other hand, the conventional surplus production models were based on the MSY estimation, which might contain uncertainties and bias due to impractical single-species approaches to be applied in the multispecies fishery (Shertzer and Williams, 2008). Regarding the comparison of the annual TAE estimations, the feedback HCR allowed the scads fishery to have more fishing trips compared to the other two HCRs to adapt a lower stock abundance index in the recent years. Nevertheless, the TAE estimations provided by three HCRs are still relatively safer than the actual fishing effort in the recent years. 
Table 2. Catch and effort data of scad fishery in 2011 $-2020$

\begin{tabular}{llll}
\hline Year & $\begin{array}{l}\text { Effort } \\
\text { (trip) }\end{array}$ & $\begin{array}{l}\text { Catch } \\
\text { (ton) }\end{array}$ & $\begin{array}{l}\text { CPUE } \\
\text { (ton/trip) }\end{array}$ \\
\hline 2011 & 319 & 651,7 & 2,04 \\
2012 & 316 & 668,2 & 2,12 \\
2013 & 313 & 684,7 & 2,19 \\
2014 & 440 & 708,4 & 1,61 \\
2015 & 400 & 732,1 & 1,83 \\
2016 & 268 & 838,6 & 3,13 \\
2017 & 868 & 945,1 & 1,09 \\
2018 & 1689 & 1196,1 & 0,71 \\
2019 & 1819 & 716,8 & 0,39 \\
2020 & 1402 & 477,1 & 0,34 \\
\hline
\end{tabular}

Description: Effort indicating the number of trips operated per year (trip), catch indicating the amount of catch landed in Tambakrejo fishing port (ton), and CPUE (catch per unit effort) indicating the stock abundance index (ton/trip)

Table 3. The annual TAC and TAE comparison among HCRs

\begin{tabular}{lccc}
\hline No Parameters & $\begin{array}{c}\text { The Schae- } \\
\text { fer model }\end{array}$ & $\begin{array}{c}\text { The Fox } \\
\text { model }\end{array}$ & $\begin{array}{c}\text { The feed- } \\
\text { back HCR }\end{array}$ \\
\hline $1 \mathrm{TAC}_{2021}$ (tons) & 1012 & 785,38 & 300,6 \\
$2 \mathrm{TAE}_{2021}$ (trips) & 550 & 440 & 763 \\
\hline
\end{tabular}

Description: $\mathrm{TAC}_{2021}$ is the estimation of total allowable catch (tons) in 2021 and $\mathrm{TAE}_{2021}$ is the estimation of total allowable effort (trips) in 2021

The impracticality of single-species surplus production models occurred due to the requirement of the species-specific data that multispecies fishery might hardly provide (Cadrin and Dickey-Collas, 2015; Hilborn and Walters, 1992). Meanwhile, the feedback HCR can estimate TAC without having species-specific data since the species can be grouped based on their growth rate with special monitoring for slow-growing minor species (Harlyan et al., 2019). The other impracticality of single-species surplus production models is their assumptions which may limit the use of these models for all types of fisheries. It was stated that the relationship between catch per unit effort and effort must be a negative correlation, which indicates the models could not work in a "healthy" fishery where an increase of effort still can increase catch per unit effort (Sartimbul et al., 2016).
The scads fishery in Blitar is a multispecies fishery that comprises of four scads species. Commonly, the multispecies fishery might raise an avoidable species aggregation problem (Harlyan et al., 2019). This problem might lead to high uncertainty in fisheries data collection and fish stock assessment (Yuniarta et al., 2017). Therefore, the feedback HCR for multispecies scads fishery in Blitar can answer the species aggregation problems, since it does not require species segregation as required by most conventional single-species approaches.

\section{Conclusion}

Compared to the HCRs of the conventional surplus production models, the application of the feedback HCR can be closer and more adaptable to the historical stock abundance, which is biologically safer to scads multispecies fishery. This research also suggested that the feedback HCR is appropriate for multispecies fisheries management where only mixed-species data are available. Therefore, the implementation of the feedback HCR in the actual multispecies fishery needs to be documented to validate the use of the feedback HCR as a preliminary management for sustainable multispecies fisheries while dealing with data-limited conditions.

\section{Acknowledgement}

Authors would like to thank to all staffs of Tambak Rejo fishing ports for their supports providing fisheries statistical data during the field study.

\section{Authors' Contributions}

All authors contributed to the final manuscript. The contribution of each author as follow, L.I.H.; devised the main conceptual ideas and drafted the manuscript. S.A.N.; collected data and designed the figures. D.S.; provided critical revision of the articles. M.A.N.; formulated discussion and designed the figures. S.P.; formulated the critical discussion. All authors discussed the results and contributed to the final manuscript.

\section{Conflict of Interest}

The authors declare that they have no competing interests of conducting this research.

\section{Funding Information}

This research was partially supported by Universitas Brawijaya with grant number: 59/UN10. F06.06/2021. 


\section{References}

Cadrin, S. X., \& Dickey-Collas, M. (2015). Stock assessment methods for sustainable fisheries. ICES Journal of Marine Science, 72(1):1-6.

Carruthers, T. R., Punt, A. E., Walters, C. J., MacCall, A., McAllister, M. K., Dick, E. J., \& Cope, J. (2014). Evaluating methods for setting catch limits in data-limited fisheries. Fisheries Research, $153: 48-68$.

Chumchuen, W., \& Chumchuen, S. V. (2019). Development of albacore tuna fishery and estimation of allowable biological catch for resource management in the Indian Ocean. Fish for the People, 17(3):3440.

Chumchuen, W., Matsuoka, T., Anraku, K., \& Arnupapboon, S. (2016). Size-selective catch in tropical tuna purse seine fishery in the Eastern Indian Ocean: Assessment on new selectivity model for purse seine net. Fisheries Science, 82(3):391-404.

Department of Fisheries and Marine Affairs East Java Province. (2020). Annual catch statistics report year 2020 of East Java Province. Surabaya: Department of Fisheries and Marine Affairs East Java Province.

Dowling, N. A., Dichmont, C. M., Haddon, M., Smith, D. C., Smith, A. D. M., \& Sainsbury, K. (2015). Guidelines for developing formal harvest strategies for data-poor species and fisheries. Fisheries Research, 171:130-140.

Goethel, D. R., Lucey, S. M., Berger, A. M., Gaichas, S. K., Karp, M. A., Lynch, P. D., \& Walter, J. F. (2019). Recent advances in management strategy evaluation: Introduction to the special issue "Under pressure: addressing fisheries challenges with management strategy evaluation." Canadian Journal of Fisheries and Aquatic Sciences, 76(10):1-8.

Harlyan, L. I., Matsuishi, T. F., \& Md Saleh, M. F. (2021). Feasibility of a single-species quota system for management of the Malaysian multispecies purse-seine fishery. Fisheries Management and Ecology, 28(2):126-137.

Harlyan, L. I., Sari, W. K., Rahma, F. M., Fuad, F., \& Rahman, M. A. (2020). Pengelolaan sumber daya ikan cakalang didaratkan di Pelabuhan Perikanan Nusantara (PPN) Prigi, Trenggalek: Aplikasi feedback harvest control rule. Marine Fisheries: Journal of Marine Fisheries Technology and Management, 11(1):111-120.
Harlyan, L. I., Wu, D., Kinashi, R., Kaewnern, M., \& Matsuishi, T. (2019). Validation of a feedback harvest control rule in data-limited conditions for managing multispecies fisheries. Canadian Journal of Fisheries and Aquatic Sciences, 76(10):1885-1893.

Hilborn, Ray, \& Ovando, D. (2014). Reflections on the success of traditional fisheries management. ICES Journal of Marine Science, 71(5):1040-1046.

Hilborn, Ray, \& Walters, C. J. (Eds). (1992). Quantitative fisheries stock assessment: Choice, dynamics and uncertainty. US: Springer.

Hoshino, E., Milner-Gulland, E. J., \& Hillary, R. M. (2012). Bioeconomic adaptive management procedures for short-lived species: A case study of Pacific saury (Cololabis saira) and Japanese common squid (Todarodes pacificus). Fisheries Research, 121-122:17-30.

Ichinokawa, M., Okamura, H., \& Kurota, H. (2017). The status of Japanese fisheries relative to fisheries around the world. ICES Journal of Marine Science, 74(5):1277-1287.

Ichinokawa, M., Okamura, H., Kurota, H., Yukami, R., Tanaka, H., Shibata, Y., \& Ohshimo, S. (2015). Searching for optimum management procedures by quantifying management objectives for Japanese domestic fishery stocks without stock biomass estimation. Nippon Suisan Gakkaishi, 81(2):206-218.

Kleisner, K., Zeller, D., Froese, R., \& Pauly, D. (2013). Using global catch data for inferences on the world's marine fisheries. Fish and Fisheries, 14(3):293-311.

Kvamsdal, S. F., Eide, A., Ekerhovd, N.-A., Enberg, K., Gudmundsdottir, A., Hoel, A. H., Mills, K. E., Mueter, F. J., Ravn-Jonsen, L., Sandal, L. K., Stiansen, J. E., \& Vestergaard, N. (2016). Harvest control rules in modern fisheries management. Elementa: Science of the Anthropocene, 4(000114):122.

Magnusson, K. G. (1992). A feedback and probing strategy to regulate harvesting from a renewable resource. Mathematical Medicine and Biology, 9:43-65.

Makino, M. (2011a). Fisheries Management in Japan. In M. Makino (Ed), A brief institutional history of Japanese fisheries management. Its institutional features and case studies. (pp. 21-39). (1st ed., Vol. 34). Netherlands: Springer. 
Makino, M. (2011b). Fisheries management in Japan. Its institutional features and case studies. (1st ed., Vol. 34). Netherlands: Springer.

Munehara, M., Kaewnern, M., Noranarttragoon, P., \& Matsuishi, T. F. (2021). Simulations of fixed closure and real-time closure to manage migratory fish species for data-limited fisheries. Ocean \& Coastal Management, 211:105736.

Newman, S. J., Brown, J. I., Fairclough, D. V., Wise, B. S., Bellchambers, L. M., Molony, B. W., Lenanton, R. C. J., Jackson, G., Smith, K. A., Gaughan, D. J., Fletcher, W. (Rick) J., McAuley, R. B., \& Wakefield, C. B. (2018). A risk assessment and prioritisation approach to the selection of indicator species for the assessment of multi-species, multi-gear, multi-sector fishery resources. Marine Policy, 88:11-22.

Ohshimo, S., \& Naya, M. (2014). Management strategy evaluation of fisheries resources in data-poor situations using an operating model based on a production model. Japan Agricultural Research Quarterly, 48(2):237-244.

Punt, A. E., Butterworth, D. S., Moor, C. L., Oliveira, D., A, J. A., \& Haddon, M. (2016). Management strategy evaluation: best practices. Fish and Fisheries, 17(2):303-334.

Sartimbul, A., Iranawati, F., Sambah, A. B., Yona, D., Hidayati, N., Harlyan, L. I., Fuad, M., \& Sari, S. (2016). Pengelolaan sumberdaya perikanan pelagis di Indonesia. In D. A. Batamia (Ed.). Malang: UB Press.

Shertzer, K. W., \& Williams, E. W. (2008). Fish assemblages and indicator species: reef fishes off the southeastern United States. Fishery Bulletin, 106(3):257-269.
Sparre, P., \& Venema, S. C. (1992). Introduction to tropical fish stock assessment. Part 1: manual. In FAO Fisheries Technical Paper. No. 306/1. Rev. 1 (Vol. 306, Issue 1). Rome: FAO.

Susanti, A., Fahrudin, A., \& Kusumastanto, T. (2020). The economic impact of IUU fishing for large pelagic capture fisheries in WPPNRI 715. Journal of Socio Economic of Fisheries, 15(2):135-144.

Suwarso, S., \& Zamroni, A. (2014). Population structure of three scads species (Decapterus spp.) in Java Sea and around Sulawesi: Recommendation of sustainable fisheries of small pelagic fisheries and evaluation of fisheries management area. Indonesian Fisheries Policy Journal, 6(2):75-86.

Suwarso, Wujdi, A., \& Fauzi, M. (2014). Exploitation and catch fluctuation of small pelagic fishes in Prigi waters, south coast of Java. Indonesian Fisheries Research Journal, 20(2):69-76.

Tanaka, S. (1980). A theoretical consideration on the management of a stock-fishery system by catch quota and on its dynamical properties. Nippon Suisan Gakkaishi, 46(12):1477-1482.

Yanto, F., Susiana, S., \& Muzammil, W. (2020). Utilization rate of brown strip red snapper (Lutjanus vitta) on Mapur waters that landing in Kelong Village, Bintan Pesisir Sub District, Bintan Regency. Journal of Tropical Fisheries Management, 4(2):1-9.

Yuniarta, S., van Zwieten, P. A. M., Groeneveld, R. A., Wisudo, S. H., \& van Ierland, E. C. (2017). Uncertainty in catch and effort data of small- and medium-scale tuna fisheries in Indonesia: Sources, operational causes and magnitude. Fisheries Research, 193:173-183. 